\title{
Questions of Identity in Children Born of War-Embarking on a Search for the Unknown Soldier Father
}

\author{
Saskia Mitreuter ${ }^{1} \cdot$ Marie Kaiser $^{1} \cdot$ Sophie Roupetz ${ }^{1} \cdot$ Barbara Stelzl-Marx $^{2} \cdot$ Philipp Kuwert $^{3} \cdot$ Heide Glaesmer $^{1}$
}

Published online: 4 July 2019

(c) The Author(s) 2019

\begin{abstract}
Objectives Children Born of War (CBOW) are important but largely uninvestigated populations. As a result of being fathered by a foreign soldier and born to a local mother, these children often struggle with identity issues and search for their absent fathers their whole lives. Despite CBOW being a part of every society, which has been involved in armed conflicts, there is almost no systematic research about them.

Methods We provided a systematic insight into issues of identity that many CBOW face throughout their lives by assessing $\mathrm{N}=146$ German and $\mathrm{N}=101$ Austrian Occupation Children born after WWII. We applied a descriptive analysis of our quantitative questionnaire data.

Results Our results suggest that CBOW were often not told the truth about their origin until they were adults. The older they were, the more the disclosure seemed to impact them. After learning the truth, almost all CBOW set out on a search for their biological fathers and wanted to get in touch. Approximately half were able to locate them but many of those had not contacted them eventually. German and Austrian Occupation Children report largely similar experiences.

Conclusions Growing up as a CBOW can come with specific difficulties. Locating and getting to know their biological father seems to be a core aspect. It seems particularly important to CBOW to find out about similarities in personality and physical appearance. The possibilities to find their fathers, however, are extremely limited. Implications of the findings are discussed within the context of limitations and potential intervening factors.
\end{abstract}

Keywords Children born of war $\cdot$ Hidden populations $\cdot$ Vulnerable populations $\cdot$ Conflict $\cdot$ Identity

Children born of war (CBOW) is the umbrella term for children, who have been born in connection with an armed conflict with one parent (typically the mother) being a member of the local community and the other parent (typically the father) being a member of foreign military forces or peacekeeping corps (Grieg 2001; Mochmann 2017). Those conflicts have happened throughout history, still happen today and will likely continue to happen in the future (Mochmann and Kleinau 2016). When military or

Saskia Mitreuter

Saskia.Mitreuter@medizin.uni-leipzig.de

1 Department of Medical Psychology and Medical Sociology, University of Leipzig, Leipzig, Germany

2 Ludwig Boltzmann Institute for Research on Consequences of War, Graz, Vienna Raabs, Austria

3 Department of Psychosomatic Medicine and Psychotherapy, HELIOS Hanseklinikum Stralsund, Stralsund, Germany peacekeeping forces get in contact with the local community, there have always been sexual encounters, which can range from romantic relationships over amicable and mutual "business arrangements", prostitution or forced prostitution to (systematic) rape of local women (Glaesmer et al. 2017; Lee 2012). There has been some attention in media and research to women experiencing war rape as in the example of the civil war in Bosnia-Herzegovina during the 1990s, but almost no attention to the children born of such rapes (Glaesmer et al. 2012). However, children who were conceived in more consensual kinds of relationships have been even more neglected in public discourse even though there is no clear evidence that is easier to grow up as a foreign soldier's child from a consensual relationship in a postconflict society than from rape (Mochmann and Larsen 2008).

CBOW are still a taboo topic in most societies and they remain a hidden population often with limited access to support networks. Maybe most is known about the children born of World War II, who are now in late adulthood (Lee 
2017). These children include for instance "Wehrmachtchildren" (children of German Wehrmacht soldiers in different European countries), "German Occupation Children", and "Austrian Occupation Children" (GOC and AOC; children, whose father belonged to one of the four allied forces based in Germany and Austria at the end of World War II and whose mother is German or Austrian respectively). Only in rare cases GOC and AOC grew up with their fathers. Some soldiers returned back home voluntarily without knowing about the pregnancy or they were aware of it and left regardless. Others were relocated forcefully by their military supervisors after their relationship with a local German woman had become public. Forced relocation was common particularly for Soviet soldiers, for whom intimate contact with German or Austrian women was considered treason (German women were suspected of spying for the enemy; Stelzl-Marx 2012). Paternity suits and child support claims were difficult to put through as foreign administrations proved to be disobliging. In the case of former Eastern Germany, as an effort to emancipate women, they were made solely responsible for their children and hence did not have the rights to officially claim support. Furthermore, many women did not know more than the forename of their child's father, which is one main factor preventing children from being able to find their fathers (Stelzl-Marx 2015).

In recent years, there has been first psychosocial research showing that GOC were at higher risk for childhood maltreatment compared with a birth-cohort-matched sample (Glaesmer et al. 2017), had significantly higher prevalence rates of traumatic events and higher point prevalence rates of full and partial posttraumatic stress disorder, depression, and somatization (Kaiser et al. 2015), and had a more insecure (dismissive and fearful) adult attachment style compared to the general population (Kaiser et al. 2016). Mothers and their CBOW often face severe social stigma and discrimination (Aßmann et al. 2015; Stelzl-Marx 2015). There are many other populations of CBOW about which even less to nothing is known on a systematic level (Mochmann 2017).

From testimonies of CBOW, it becomes evident that issues revolving around the topic of identity might be amongst the most fundamental challenges to them. Cultural and biological belonging are two core aspects of identity development. In their social environment CBOW often face discrimination. This can stem from the stigma that adheres to being born out of wedlock. But CBOW are also often seen as children of the enemy or at least perceived as different to the others and are therefore marginalized or treated differently. Many feel reduced to their fathers' origins and feel they do not belong to the culture they have grown up in.

In this article, we will focus on the uncertainty about their biological origin, which is a persisting aspect that challenges their development and well-being (Lee 2017).
The question of identity, which origins in the past ("Where do I come from?") spans the whole life from present ("Who am I?") into the future ("Who will I be?"; McAdams 2001) and leaves many $\mathrm{CBOW}$ with an impaired sense of belonging and purpose. Almost all CBOW have grown up without any knowledge and narratives about their fathers and mostly even a conspiracy of silence around him. To talk or ask about the father has often been an explicit or implicit taboo in the families irrespective of the nature of their parents' relationship. This has left many CBOW with questions and doubts about who their fathers are and not last who they themselves are. Albeit this being a core aspect in the life of CBOW, there has been no study to date that has systematically investigated the topic of identity in a CBOW population. Fundamental questions remain unknown, for example how groups of CBOW differ from each other in their experience of being a CBOW; How and when the truth about their biological origins is revealed to them; How the father's background as an (enemy) soldier influences their stand in their communities and their self-perception; Why and how do CBOW search for their unknown fathers; And: If they locate and contact their fathers or family members, how does this influence them and their sense of identity?

The aim of this study was to shed some light on these issues by providing a descriptive analysis of questions related to their fathers' biological origin, their search for their fathers, and how they perceive and characterize themselves in the context of being a CBOW, in a sample of German Occupation Children and a sample of Austrian Occupation Children born after WWII, who were on average 64 years old at the time of assessment, and to compare the two groups.

Our questions were in particular: When was the truth about their origin disclosed to German and Austrian occupation children and what impact did this have on them?; How does the father's origin as an occupation soldier influence their self-perception?; Is there a wish for contact to the unknown fathers and what are $\mathrm{CBOW}$ curious to find out about their fathers?; How many CBOW and how do CBOW search for their fathers and how was an eventual contact experienced?; and last: Do German and Austrian Occupation Children differ in those respects?

\section{Method}

\section{Participants}

\section{German occupation children (GOC)}

We collected a sample of GOC $(\mathrm{N}=146)$ within the project "Occupation children: Identity development, stigma experience, and psychosocial consequences growing up as a 
German Occupation Child". 184 questionnaires were sent out and 164 were returned of which 9 had to be excluded because they did not fit the definition of "occupation children". The participation rate was hence $88.6 \%$, corrected for neutral drop-outs. We excluded another 9 cases to correct for outliers with respect to age, leaving 146 valid cases, which were born between 1945 and 1966. 63\% of the sample were female with a mean age of $63.4(\mathrm{SD}=5.7)$ years. $48.6 \%(n=71)$ of GOC had a US American father, $22.6 \%(\mathrm{n}=33)$ had a French (or French-Algerian/-Moroccan/-Corsican) father, $21.9 \%(\mathrm{n}=32)$ had a Soviet father, $4.1 \%(n=6)$ had a British father. Of those GOC, $9.9 \%$ $(\mathrm{n}=14)$ were not sure about their fathers' origin. Overall $2.7 \%(n=4)$ did not know their father's origin at all. More information about the methodological approach, sample characteristics, and background of the study are provided in (Kaiser et al. 2015). The study was reviewed and approved by the ethics committee of the Medical Faculty of the University of Leipzig.

\section{Austrian occupation children (AOC)}

Subsequent to the data collection in Germany in 2013, we collected a sample of Austrian occupation children (AOC; $\mathrm{N}=101$ ). A total of 164 questionnaires were sent out and 107 were returned of which 4 had to be excluded because they did not fit the definition of "occupation children" and 2 were excluded because of too many missing values, resulting in a participation rate of $63.9 \%$ and hence 101 valid cases, which were born between 1945 and 1966. Overall $66.3 \%$ of the sample were female with a mean age of $63.5(\mathrm{SD}=11.6)$ years. $38.6 \%(\mathrm{n}=39)$ AOC stated to have a US American father, $13.9 \%(\mathrm{n}=14)$ a French (or French-Algerian/-Moroccan/-Corsican) father, $25.7 \%(\mathrm{n}=$ 26) a Soviet father, and $15.8 \%(\mathrm{n}=16)$ a British father. Of those AOC, $7.4 \%(n=7)$ were not sure about their fathers' origin. $5.9 \%(n=6)$ did not know their father's origin at all. The study was reviewed and approved by the ethics board of the first author's institution and the ethics committee of Graz University.

\section{Procedure}

\section{German occupation children (GOC)}

Participants were recruited via press releases, various national and international networks (e.g. www. childrenbornofwar.org; www.bowin.eu), and onlineplatforms for occupation children and children born of war in general (e.g. www.gitrace.org; www.coeurssa nsfrontiers.com). Within these calls, we invited potential participants to contact our research group to learn more about the project and to leave their contact details. Inclusion criteria were being born after 1940 to a German mother, being fathered by a soldier of one of the foreign occupation forces, and being able to understand and read the German language. Questionnaires, a study information sheet, and consent forms were subsequently sent to interested GOC via postal mail. We collected the data between March and December 2013.

\section{Austrian occupation children (AOC)}

Participants were recruited via a nationwide media campaign initiated by the head of the Ludwig Boltzmann Institute for Research on Consequences of War (BIK; http:// bik.ac.at/), including press releases in print media and on websites of official institutions such as the BIK. We furthermore reached out to potential participants via announcements on national radio and television and through personal contacts. The subsequent procedure was equivalent to the German study. We collected data between October 2013 and October 2014.

\section{Measures}

Children born of war are a hidden population, which is difficult to access for researchers and whose specific experiences are not accounted for by established instruments (Mochmann 2013). For this reason, we acted twofold: We applied a participatory approach to develop questions and items that - amongst other topics - address aspects of identity (e.g. search for father, questions about origin, background of procreation, and feelings of e.g. shame, pride, and belonging) of GOC and AOC adequately. By inviting both experts and members of the target group to actively collaborate in the designing of the questionnaire, we created maximum proximity to the target group and ensured the relevance of the topics covered and questions asked (Brendel 2002; Kaiser et al. 2016). To design the questionnaire, we first derived and adopted questions about experiences during childhood and adolescence and father's origin from existing literature in history and the social sciences (Chaitin 2003; Mochmann and Larsen 2008; Mochmann et al. 2009). Second, items were analyzed during discussions in focus groups, need analysis, and item ranking by GOC $(\mathrm{N}=4)$ and Norwegian Wehrmacht-children $(\mathrm{N}=3)$ to ensure content validity, completeness, and comprehensiveness (GESIS, 2013; Kaiser et al. 2016). Finally, four subjects of the target group as well as expert colleagues from sociology, history, and psychiatry pilot tested the questionnaire.

For the Austrian Occupation Children, we applied the same questionnaire with some minor linguistic adaptations. The German and Austrian complete versions of the questionnaire as well as their English translation can be requested from the first author. 
Disclosure of truth about the biological father and its impact

To assess how occupation children found out the truth about their origin and what impact this had on them, we asked two questions: "How old were you approximately when you found out that your biological father was an occupation soldier?". To answer, participants entered their age: "_years old". And "Did you change as a person after having found out that your biological father was an occupation soldier?". Participants indicated change on a 4-point Likert scale ranging from 1 (yes, changed very much) to 4 (no, didn't change at all.)

\section{The father's origin and its influence on self-perception}

To answer how participants perceived themselves as an occupation child, i.e. their biological father being an occupation soldier, we asked "In which way did your knowledge about your father affiliated to an occupation force influence how you see yourself?". 11 items could be answered on a 4point Likert scale: (1) Strongly disagree, (2) Rather disagree, (3) Rather agree, and (4) Strongly agree. Before the Likert-scale, there was an option to score "Not applicable". We will discuss implications of this option later. To make our descriptive analyses more straightforward, readable, and clear, we dichotomized the item scores into Disagree (Strongly disagree and Rather disagree) and Agree (Rather agree and Strongly agree). Examples for items are "I felt ashamed to be an "occupation child", (reverse coded), "I was proud of my biological origin", "I didn't have any issues with my father's biological background", and "I often had a feeling that 'proper' Germans considered us inferior" (reverse coded).

\section{Reasons for curiosity about the unknown father and wish for contact}

Participants were asked "In which way was it important for you to resolve issues around your biological origin, i.e. to find out about being an occupation child and to find out about who your parents are or who your father is respectively?" Answers were scored on the same 4-point Likert scale as above ranging from 1 (Strongly disagree) to 4 (Strongly agree). Before the Likert-scale, there was an option to score "Not applicable". We also dichotomized the scale as we described above. The 13 items included statements such as "I needed clarity about a part of my life that I couldn't remember myself", "Finding out the truth took a great effort from me", "I had missed to be part of a more extended family for a long time", and "It was important for me to explore my biological origin, because my children kept asking me about it".

\section{The search for their fathers and actual contact}

Several short questions were posed to inquire about if and how participants searched for their fathers and how the eventual contact to them turned out. Exemplary questions were "Did you search for your biological father?", (1) yes, (2) no; "If yes, how did you search?", (1) alone, (2) with the help of third parties; "Have you found your biological father?", (1) yes, (2) no; "If yes, have you contacted him?", (1) yes, (2) (no), and "If yes, how did the contact turn out?" (1) Positive, because (2) Negative, because

\section{Data Analyses}

To answer our research questions, we conducted descriptive analyses using the software SPSS 24 . We report percentages and absolute numbers. To test the impact of their age at disclosure (independent variable) on how much they felt they changed as a person (dependent variable) we conducted a linear regression analysis. For an initial missing values analysis, we conducted t-tests for independent samples.

\section{Results}

We conducted a missing values analysis for all study variables to account for potential bias and its impact on interpreting our results. The results of this analysis indicated that missing values of our study variables were missing at random. Age of the participants seemed to have a small effect on the response behavior to three of the scale items of study interest. Further, missingness on scale items was associated with missingness on some of the other scale items as well. Other than that, missingness on study variables was at random and was also not associated with other sociodemographic variables.

\section{Parental Relationship and Background of Procreation}

All participants entered a valid response to the question surrounding their background of procreation. Overall $68.5 \%(n=100)$ of GOC and $68.3 \%(n=69)$ of AOC indicated that they were conceived of love, while $6.8 \%$ (n $=10)$ of GOC and $2 \%(\mathrm{n}=2)$ of AOC reported to know that they were conceived of rape. $17.8 \%(n=26)$ of GOC and $22.8 \%(n=23)$ of AOC were not sure about the background of their procreation and $6.8 \%(n=10)$ GOC and $7 \%(\mathrm{n}=7)$ AOC indicated that the parental relationship was something other than the above (e.g. "businessarrangement"). 


\section{Disclosure of Truth about the Biological Father and its Impact}

Of 146 GOC, 142 and of 101 AOC, 97 entered a valid response to the question about when the truth about their origin was disclosed to them. Not more than approximately one third of GOC $(n=46)$ and AOC $(n=36)$ knew about their origin since they could remember or some point in early childhood (between 3 and 7 years). Another third learned about it in late childhood (8-12 years), while another $13 \%(n=19)$ of GOC and only $5 \%(n=5)$ of AOC learned about their origin after the age of 30 . Six German Occupation Children learned the truth about their origin at the age of 60 or later. The mean age at disclosure was 14.94 years $(\mathrm{SD}=15.23)$ for $\mathrm{GOC}$ and 11.59 years $(\mathrm{SD}=10.10)$ for AOC. More than half of the German and Austrian participants indicated not having changed at all as a person, while $15 \%$ in both samples report having changed very much (GOC: $\mathrm{M}=3.10, \mathrm{SD}=1.15$; $\mathrm{AOC}: \mathrm{M}=3.17$, $\mathrm{SD}=$ 1.13). There is a small, but statistically significant tendency that both, GOC and AOC experienced a stronger change in how they felt as a person after finding out the truth the older they were when it happened (GOC: $t=-0.172, p<0.05$; AOC: $\mathrm{t}=-0.208, p<0.05)$.

\section{The Father's Origin and its Influence on Self- Perception}

Table 1 shows the number and percentage of participants, who had missing values or who indicated that the respective item was irrelevant to them. Of the remaining responses, $81.3 \%(\mathrm{n}=87)$ of GOC and $86.6 \%(\mathrm{n}=71)$ of AOC stated not having a problem with the biological origin of their father. Only $16.4 \%(\mathrm{n}=24)$ of GOC and $17.8 \%(\mathrm{n}=18)$ of AOC felt inferior to others because their father belonged to one of the occupation forces or felt ashamed of being an occupation child, but more than half of GOC and AOC $(62.1 \%, \mathrm{n}=54 ; 71.1 \%, \mathrm{n}=38)$ felt that the "proper Germans" or "proper Austrians", respectively, considered them inferior.

\section{Reasons for Curiosity about the Unknown Father and Wish for Contact}

Table 2 shows the number and percentage of participants, who had missing values or who indicated that the respective item was irrelevant to them. We subsequently report percentages of the remaining responses. When reporting why it was important for them to know more about their biological origin, over $80 \%(n=84$ GOC; $n=53$ AOC $)$ of both, German and Austrian Occupation Children indicated that the "black hole" in their biographies had been bothering them for a long time and $69.2 \%(n=56)$ of GOC and
Table 1 Invalid and valid responses for items about the father's background and its influence on self-perception

\begin{tabular}{|c|c|c|c|c|}
\hline & \multicolumn{2}{|c|}{$\begin{array}{l}\text { German occupation } \\
\text { children }\end{array}$} & \multicolumn{2}{|c|}{$\begin{array}{l}\text { Austrian occupation } \\
\text { children }\end{array}$} \\
\hline & $\mathrm{N}$ & $\%$ & $\mathrm{~N}$ & $\%$ \\
\hline \multicolumn{5}{|c|}{$\begin{array}{l}\text { "I did not have a problem with the biological background of my } \\
\text { father" }\end{array}$} \\
\hline $\begin{array}{l}\text { "Not } \\
\text { applicable" }\end{array}$ & 24 & 16.4 & 14 & 13.9 \\
\hline Missing values & 15 & 10.3 & 5 & 5 \\
\hline Valid responses & 107 & 73.3 & 82 & 81.2 \\
\hline Total & 146 & 100 & 101 & 100 \\
\hline Mean, SD & $\begin{array}{l}\text { M (3.32), } \\
\text { SD (0.95) }\end{array}$ & & $\begin{array}{l}\mathrm{M}(3.57) \\
\mathrm{SD}(0.88)\end{array}$ & \\
\hline Min, Max & $\operatorname{Min}(1), \operatorname{Max}(4)$ & & $\operatorname{Min}(1), \operatorname{Max}(4)$ & \\
\hline \multicolumn{5}{|c|}{$\begin{array}{l}\text { "I felt inferior to others because my father belonged to the occupation } \\
\text { force" }\end{array}$} \\
\hline $\begin{array}{l}\text { "Not } \\
\text { applicable" }\end{array}$ & 68 & 46.6 & 54 & 53.5 \\
\hline Missing values & 12 & 8.2 & 7 & 6.9 \\
\hline Valid responses & 66 & 45.2 & 40 & 39.6 \\
\hline Total & 146 & 100 & 101 & 100 \\
\hline Mean, SD & $\begin{array}{l}\mathrm{M}(2.09) \\
\mathrm{SD}(1.12)\end{array}$ & & $\begin{array}{l}\mathrm{M}(2.20) \\
\mathrm{SD}(1.22)\end{array}$ & \\
\hline Min, Max & $\operatorname{Min}(1), \operatorname{Max}(4)$ & & $\operatorname{Min}(1), \operatorname{Max}(4)$ & \\
\hline \multicolumn{5}{|c|}{$\begin{array}{l}\text { "I often had a feeling that the 'proper' Germans/Austrians considered } \\
\text { us inferior" }\end{array}$} \\
\hline $\begin{array}{l}\text { "Not } \\
\text { applicable" }\end{array}$ & 49 & 33.6 & 38 & 37.6 \\
\hline Missing values & 10 & 6.8 & 10 & 9.9 \\
\hline Valid responses & 87 & 59.6 & 53 & 52.5 \\
\hline Total & 146 & 100 & 101 & 100 \\
\hline Mean, SD & $\begin{array}{l}\text { M }(2.70) \\
\text { SD }(0.99)\end{array}$ & & $\begin{array}{l}\mathrm{M}(2.81) \\
\mathrm{SD}(1.13)\end{array}$ & \\
\hline Min, Max & $\operatorname{Min}(1), \operatorname{Max}(4)$ & & $\operatorname{Min}(1), \operatorname{Max}(4)$ & \\
\hline
\end{tabular}

All items were scored on a 4-point Likert-scale: (1) Strongly disagree, (2) Rather disagree, (3) Rather agree, (4) Strongly agree

$65.4 \%(\mathrm{n}=36)$ of AOC agreed that this hole had been filled due to learning more about their origin. Overall $93.5 \%$ $(n=100)$ of GOC and $92.8 \%(n=64)$ of AOC stated that they were happy to learn more about their father and that it "helped to put together pieces of the puzzle", even if the process of finding out took great efforts for many of them. When we asked GOC and AOC why they felt the need to find out more about their biological father, very few of them wanted to contact their father about hereditary entitlement $(4.6 \%, \mathrm{n}=2$ of GOC but $11.1 \%, \mathrm{n}=3$ of AOC) or confront him with the fact that he had abandoned them $(34.9 \%, \mathrm{n}=$ 22 of GOC but $53.3 \%, \mathrm{n}=24$ of AOC). Between $47.5 \%$ ( $=48)$ and $66.3 \%(n=67)$ of occupation children, however, indicated that those two items did not apply to them, so the valid cases were already few to start with (see Table 2). A 
Table 2 Invalid and valid responses for items about reasons for curiosity about the unknown father and wish for contact

\begin{tabular}{lll} 
German occupation children & \multicolumn{2}{l}{$\begin{array}{l}\text { Austrian occupation } \\
\text { children }\end{array}$} \\
\cline { 1 - 2 } & $\%$ & $\mathrm{~N}$
\end{tabular}

"The 'black hole' in my biography had been bothering me for a long time"

\begin{tabular}{|c|c|c|c|c|}
\hline $\begin{array}{l}\text { "Not } \\
\text { applicable" }\end{array}$ & 28 & 19.2 & 27 & 26.7 \\
\hline Missing values & 16 & 11.0 & 12 & 11.9 \\
\hline Valid responses & 102 & 69.9 & 62 & 61.4 \\
\hline Total & 146 & 100 & 101 & 100 \\
\hline Mean, SD & $\begin{array}{l}\text { M (3.40), } \\
\text { SD (0.90) }\end{array}$ & & $\begin{array}{l}\text { M (3.50), } \\
\text { SD (0.83) }\end{array}$ & \\
\hline Min, $\max$ & $\operatorname{Min}(1), \max (4)$ & & $\operatorname{Min}(1), \max (4)$ & \\
\hline
\end{tabular}

"Knowing about my biological origin filled the 'black hole' in my biography"

$\begin{array}{lllll}\begin{array}{l}\text { "Not } \\ \text { applicable" }\end{array} & 46 & 31.5 & 33 & 32.7 \\ \text { Missing values } & 19 & 13.0 & 13 & 12.9 \\ \text { Valid responses } & 81 & \mathbf{5 5 . 5} & 55 & \mathbf{5 4 . 5} \\ \text { Total } & 146 & 100 & 101 & 100 \\ \text { Mean, SD } & \text { M (3.00), } & & \text { M (3.11), } & \\ & \text { SD (0.96) } & & \text { SD (1.05) } \\ \text { Min, max } & \text { Min(1), max(4) } & & \text { Min(1), max(4) }\end{array}$

"I was happy to learn more about my father"

$\begin{array}{llll}\begin{array}{lll}\text { "Not } \\ \text { applicable" }\end{array} & 24 & 16.4 & 19 \\ \text { Missing values } & 15 & 10.3 & 13 \\ \text { Valid responses } & 107 & \mathbf{7 3 . 3} & 69 \\ \text { Total } & 146 & 100 & 101 \\ \text { Mean, SD } & \mathrm{M}(3.64), & & \mathrm{M}(3.71), \\ & \mathrm{SD}(0.60) & & \mathrm{SD}(0.60) \\ \text { Min, max } & \operatorname{Min}(2), \max (4) & & \operatorname{Min}(2), \max (4)\end{array}$

"It took me great efforts to find out more"

\begin{tabular}{|c|c|c|c|}
\hline $\begin{array}{l}\text { "Not } \\
\text { applicable" }\end{array}$ & 36 & 24.7 & 16 \\
\hline Missing values & 18 & 12.3 & 13 \\
\hline Valid responses & 92 & 63.0 & 72 \\
\hline Total & 146 & 100 & 101 \\
\hline Mean, SD & $\begin{array}{l}\text { M (3.26), } \\
\text { SD (0.97) }\end{array}$ & & $\begin{array}{l}\mathrm{M}(3.52) \\
\mathrm{SD}(0.73)\end{array}$ \\
\hline Min, $\max$ & $\operatorname{Min}(1), \max (4)$ & & $\operatorname{Min}(1), \max (4)$ \\
\hline \multicolumn{4}{|c|}{ "I wanted to contact my father to claim hereditary titles" } \\
\hline $\begin{array}{l}\text { "Not } \\
\text { applicable" }\end{array}$ & 92 & 63.0 & 67 \\
\hline Missing values & 10 & 6.9 & 7 \\
\hline Valid responses & 44 & 30.1 & 27 \\
\hline Total & 146 & 100 & 101 \\
\hline Mean, SD & $\begin{array}{l}\mathrm{M}(1.26) \\
\text { SD (0.62) }\end{array}$ & & $\begin{array}{l}\text { M (1.48), } \\
\text { SD (0.89) }\end{array}$ \\
\hline Min, Max & $\operatorname{Min}(1), \max (4)$ & & $\operatorname{Min}(1), \max (4)$ \\
\hline
\end{tabular}

68.3

100

18.8

9

3

(1)

Table 2 (continued)

\begin{tabular}{|c|c|c|c|c|}
\hline & \multicolumn{2}{|c|}{ German occupation children } & \multicolumn{2}{|c|}{$\begin{array}{l}\text { Austrian occupation } \\
\text { children }\end{array}$} \\
\hline & $\mathrm{N}$ & $\%$ & $\mathrm{~N}$ & $\%$ \\
\hline \multicolumn{5}{|c|}{ "I wanted to confront him with the fact that he had abandoned me" } \\
\hline $\begin{array}{l}\text { "Not } \\
\text { applicable" }\end{array}$ & 71 & 48.6 & 48 & 47.5 \\
\hline Missing values & 12 & 8.2 & 8 & 7.9 \\
\hline Valid responses & 63 & 43.2 & 45 & 44.6 \\
\hline Total & 146 & 100 & 101 & 100 \\
\hline Mean, SD & $\begin{array}{l}\mathrm{M}(2.06) \\
\mathrm{SD}(1.19)\end{array}$ & & $\begin{array}{l}\mathrm{M}(2.58) \\
\mathrm{SD}(1.23)\end{array}$ & \\
\hline Min, $\max$ & $\operatorname{Min}(1), \max (4)$ & & $\operatorname{Min}(1), \max (4)$ & \\
\hline \multicolumn{5}{|c|}{$\begin{array}{l}\text { "I wanted to get to know my father personally and be in touch with } \\
\text { him" }\end{array}$} \\
\hline $\begin{array}{l}\text { "Not } \\
\text { applicable" }\end{array}$ & 22 & 15.1 & 13 & 12.9 \\
\hline Missing values & 11 & 7.5 & 8 & 7.9 \\
\hline Valid responses & 113 & 77.4 & 80 & 79.2 \\
\hline Total & 146 & 100 & 101 & 100 \\
\hline Mean, SD & $\begin{array}{l}\mathrm{M}(3.61) \\
\mathrm{SD}(0.63)\end{array}$ & & $\begin{array}{l}\mathrm{M}(3.56) \\
\mathrm{SD}(0.73)\end{array}$ & \\
\hline Min, $\max$ & $\operatorname{Min}(1), \max (4)$ & & $\operatorname{Min}(1), \max (4)$ & \\
\hline \multicolumn{5}{|c|}{$\begin{array}{l}\text { "I was curious about similarities in personality, talents, and physical } \\
\text { appearance." }\end{array}$} \\
\hline $\begin{array}{l}\text { "Not } \\
\text { applicable" }\end{array}$ & 12 & 8.2 & 10 & 9.9 \\
\hline Missing values & 10 & 6.9 & 7 & 6.9 \\
\hline Valid responses & 124 & 84.9 & 84 & 83.2 \\
\hline Total & 146 & 100 & 101 & 100 \\
\hline Mean, SD & $\begin{array}{l}\mathrm{M}(3.65) \\
\mathrm{SD}(0.60)\end{array}$ & & $\begin{array}{l}\mathrm{M}(3.64) \\
\mathrm{SD}(0.61)\end{array}$ & \\
\hline Min, $\max$ & $\operatorname{Min}(1), \max (4)$ & & $\operatorname{Min}(1), \max (4)$ & \\
\hline \multicolumn{5}{|c|}{$\begin{array}{l}\text { "I wanted to know more about my father because I feel/felt lonely in } \\
\text { this world and wish/wished for a family" }\end{array}$} \\
\hline $\begin{array}{l}\text { "Not } \\
\text { applicable" }\end{array}$ & 49 & 33.6 & 42 & 41.6 \\
\hline Missing values & 18 & 12.3 & 8 & 8.9 \\
\hline Valid responses & 79 & 54.1 & 50 & 49.5 \\
\hline Total & 146 & 100 & 101 & 100 \\
\hline Mean, SD & $\begin{array}{l}\text { M (3.08), } \\
\text { SD (0.96) }\end{array}$ & & $\begin{array}{l}\mathrm{M}(3.32) \\
\mathrm{SD}(0.96)\end{array}$ & \\
\hline Min, $\max$ & $\operatorname{Min}(1), \max (4)$ & & $\operatorname{Min}(1), \max (4)$ & \\
\hline
\end{tabular}

All items were scored on a 4-point Likert-scale: (1) Strongly disagree,

(2) Rather disagree, (3) Rather agree, (4) Strongly agree

26.7

100

vast majority instead wished to get to know their father personally and be in touch with him $(93.8 \%, \mathrm{n}=106$ of GOC; $91.3 \%, \mathrm{n}=73$ of AOC) and almost all occupation children indicated to be curious about e.g. similarities in personality, talents and physical appearance. Overall $73.4 \%$ $(\mathrm{n}=58)$ of GOC and $82 \%(\mathrm{n}=41)$ of AOC wanted to get 
to know more about their father because they had "felt lonely in this world and were wishing for a family".

\section{The Search for their Fathers and Actual Contact}

The majority of German Occupation Children $(73.6 \%, \mathrm{n}=$ 108) and Austrian Occupation Children $(67.7 \%, \mathrm{n}=68)$ were looking for their biological father, of which almost all ( $n=107$ of GOC and $n=66$ of AOC) were searching with some help of institutions or others. Overall $39 \%(n=78)$ of GOC and $27.7 \%(n=43)$ of AOC found out his contact details but in $22.6 \%(\mathrm{n}=33)$ for GOC and $13.6 \%(\mathrm{n}=14)$ for AOC of those cases he had already passed away. After finding out his contact details, close to $80 \%$ of those GOC and AOC contacted him or other family members in case of his decease. For approximately half of the GOC and AOC, this contact was positive, for the other half it was negative. To have found other relatives, in particular other (half-) siblings, was the most commonly reported positive outcome. The most common negative experience was that fathers did not respond to letters at all or denied paternity.

\section{Discussion}

From every armed conflict, children are born, who are fathered by foreign soldiers and born to local mothers. These children often grow up under impeded conditions on a societal and familial level. For most, one major aggravating factor is the circumstance, that their father is not only absent, but that there is a conspiracy of silence surrounding him, leaving those children unsure and doubtful about a part of their own identity. Despite CBOW being a universal phenomenon that is likely to continue existing in the future, little is known about them on a systematic level and there is still much to learn.

This study explored and compared identity issues in two CBOW populations. For this purpose, a sample of GOC and a sample of AOC were assessed in a cross-sectional study. The results suggest that in general, GOC and AOC had very similar experiences growing up as CBOW. Only few cases were knowingly conceived of rape. Interestingly however, although roughly one fifth of GOC and AOC report being unsure about the nature of their biological parents' relationship and only approximately $70 \%$ report being conceived of love, a vast majority of all occupation children (81.9\%, N = 120 of GOC; $91.1 \%, \mathrm{~N}=92$ of AOC) report being convinced that their father was their "mother's love of her life". This discrepancy could be explained by the fact that most occupation children want to see their biological father and their parents' relationship in a positive light to be able to maintain a positive self-perception and sense of worthiness even though little or nothing is known about the nature of their parents' relationship. In most families it was a taboo to talk about anything related to the missing father and the children had great difficulties to break this wall of silence, for example out of fear to hurt or anger their mothers. Within a follow-up interview study with ten GOC, it became evident that many occupation children might still show a strong sense to protect their mothers and do not judge her choice of having had intimate contact with an occupation soldier, which could be another reason for imagining their biological parents' relationship so positively. As such, only few ( $\mathrm{N}=5 \mathrm{GOC}, \mathrm{N}=5 \mathrm{AOC})$ report feeling ashamed for their mother that she had sexual contact with an occupation soldier and over $90 \%$ of GOC and AOC think that it is her own business.

Roughly one third of the occupation children learned the truth about their origin after entering adulthood, some even very late in life. Finding out later in life seems to be connected to a stronger change as a person. In the follow-up interviews, some GOC report that they experienced it as a shock that shattered their assumptions about themselves and the trust in their family members to learn that they were not who they thought they were (e.g. the son or daughter of their step-father), especially if they learned about this in late adulthood, which sometimes meant even after their mother had died. They often emphasized the importance of learning the truth about oneself (i.e. about where one truly comes from, which for many means who one truly is) as early as possible in order to be able to integrate this knowledge into ones identity and biographical narrative. This assumption has been supported by studies on adopted and so-called sperm donor offspring (Freeman 2015; Freeman and Golombok 2012; Golombok et al. 2013; Ilioi et al. 2017). Our results suggest that most of the participants themselves weren't ashamed of being children born of war (i.e. no reported self-stigma), but that they felt considered inferior nonetheless by their social environments, i.e. were subjected to social stigma (Aßmann et al. 2015).

Our results revealed that the fundamental need to find out more about their second biological half, i.e. their biological father, is one core aspect that defines being a CBOW as almost all occupation children wanted to know more about their fathers, especially regarding personality, talents, and physical appearance and wanted to get to know him personally. In the meantime, Germany and Austria have established a right to know about who ones biological parents are. But there are many other countries, where children and adults cannot benefit from such a right.

Many had felt lonely and were wishing for a family. This could be due to the fact that many of the GOC remained without siblings after their mother had given birth to them, because the mothers often faced discrimination and stigmatization after having been sexually involved with an occupation soldier, who was often considered "the enemy" in addition to having given birth to a child out of wedlock 
(Aßmann et al. 2015; Glaesmer et al. 2012; Satjukow 2009). GOC often report a feeling of not belonging anywhere, also within their families and that they felt they had been different from the other family members even a long time before finding out about their true origin. As one occupation child put it: "As a child I knew that I was a bastard. I felt it." (ID 151, A27). Only few occupation children in general wanted to contact their fathers about financial matters or to confront him. Interestingly, however, AOC wanted to do so twice as often as GOC. This might be explained by the fact that many Germans were racked with guilt after WWII, which in GOC could have expressed itself by feeling ashamed to make any demands, especially on someone of a foreign nation, whom they might consider a liberator of Nazi-Germany. Austrians at the same time traditionally tend to view themselves in the position of victims of the Hitleraggression for example, and therefore might as well in this context consider themselves victims with a right for compensation.

Despite most occupation children embarking on a search for their fathers, only approximately half of them could eventually locate their fathers, deceased or alive. Still, one fifth of those finding out his contact details did not contact him or remaining family members in the end. Fear of being rejected might be one reason for this, as this was also the most commonly reported negative outcome of contacting him or family members. One participant mentioned in an interview that it was most important to have proven that he had a father at all, to know his existence and that this was more crucial than getting to know him so late in life ("I could finally and proudly say that I knew who my father was, that I had a father at all"; Interview \#9, p.24, 1023). Others had been yearning to meet their biological father their whole lives.

Unfortunately, the standardized questionnaire items did not allow an analysis of how CBOW experienced the contact to their fathers or newly found family members and how this influenced them. Further studies of preferably qualitative nature are necessary for more in-depth insight. However, the results of this study and preliminary analysis of the follow-up interviews indicate that questions of identity for occupation children and maybe CBOW in general are closely linked to questions of belonging. Finding their father seems to imply feeling complete and finding some peace for many occupation children.

\section{Limitations}

The present study had several limitations that have to be critically reflected. First, due to the nature of data collection and the CBOW populations qualifying as hidden populations, our two samples were self-selective and therefore potentially non-representative. The authors reached out for participants publicly, who then reacted if they were interested in participating. Some participants were reached via snow-balling. Nevertheless, as the entire population is unknown it is impossible to conduct a representative study in this target group. Second, we adopted the option to score "Not applicable" for some item batteries, a measure, which has left us with a sometimes smaller percentage of valid responses as we hoped for. The pitfall here is that we cannot know why participants scored "Not applicable". In some cases, it seems to be due to the fact that the questions were formulated in an emotionally valent way that participants might have tried to avoid, consciously or unconsciously. In an effort to adopt the previously existing instruments by Mochmann and Larsen (2008) and on the basis of the results of our participatory pilot-study, we deemed it unproblematic to apply it. For future studies using our instruments, we highly recommend dropping this option. Third, our study is of cross-sectional nature and the participants answered the questions retrospectively, which makes our data subject to the potential bias of retrospective self-report. The data is only a reflection of the current status when interviewed. Fourth, our results might not be generalizable to other $\mathrm{CBOW}$ populations due to cultural specificities and other specific circumstances, such as the type of war for instance. Other studies might yield other results, which is why replication studies in other CBOW populations are much needed. Future research on CBOW should focus on systematic analyses and possibly standardization of instruments to allow for comparisons of different CBOW populations. And fifth, a scientifically new and complex phenomenon such as identity in CBOW is difficult to explore and understand with quantitative means and warrants for more open and indirect assessment.

The limitations above notwithstanding, our study provides some systematic evidence of identity questions in a neglected, and yet important population. CBOW are a universal and international, but marginalized subgroup of each society that has been involved in armed conflicts. Our study added to the evidence that being a CBOW can come with specific difficulties. Locating and getting to know their biological father seems to be a core aspect of being a CBOW. It seems particularly important to CBOW to find out about similarities in personality, talents, and physical appearance. The possibilities to find their fathers, however, are extremely limited due to national policies.

To formulate practical implications, further systematic research is needed. It remains unclear for example, which identities emerge in narratives of CBOW or in which contexts which aspects of their identities as CBOW seem to be more hindering - being born out of wedlock, being seen as a child of the enemy, looking foreign and receiving racist treatment for it or more indirect features such as low socioeconomic status e.g. as a result of discrimination against their 
mothers. As CBOW are still a rather novel target group, we advise to conduct more qualitative research in order to enable CBOW to use and create their own terms and meanings.

Funding This project has received funding from the European Union's Horizon 2020 research and innovation programme under the Marie Sklodowska-Curie grant agreement No 642571 (Network website: www.chibow.org) and from the State of Saxony [Grant number WEV-G-07-2-0612]. The University of Greifswald [BMBF grant number (FONE-100)] supported the start of the project with a starting grant for material.

Authors' Contributions S.M. ran the data analyses, and wrote the paper. M.K. designed and executed the questionnaire study for the German sample and collaborated in the editing of the final manuscript. S.R. collaborated in the editing of the final manuscript. B.S.M. executed the questionnaire study for the Austrian sample and collaborated in the editing of the final manuscript. P.K. collaborated in designing the questionnaire study for the German sample and the editing of the final manuscript. H.G. designed and executed the questionnaire study for the German sample and collaborated in the editing of the final manuscript.

\section{Compliance with Ethical Standards}

Conflict of Interest The authors declare that they have no conflict of interest.

Ethical Approval All procedures performed in studies involving human participants were in accordance with the ethical standards of the institutional research committee and with the 1964 Helsinki declaration and its later amendments or comparable ethical standards. The study protocol was approved by the ethics committees of the University of Leipzig (415-12-17122012) and the University of Graz $(39 / 27 / 63$ ex 2015/10).

Informed Consent Prior to participation, all subjects were informed about the purpose of the study, the voluntary nature of their participation, data storage and security. They gave written informed consent before participating.

Publisher's note: Springer Nature remains neutral with regard to jurisdictional claims in published maps and institutional affiliations.

Open Access This article is distributed under the terms of the Creative Commons Attribution 4.0 International License (http://crea tivecommons.org/licenses/by/4.0/), which permits unrestricted use, distribution, and reproduction in any medium, provided you give appropriate credit to the original author(s) and the source, provide a link to the Creative Commons license, and indicate if changes were made.

\section{References}

Aßmann, A.-L., Kaiser, M., Schomerus, G., Kuwert, P., \& Glaesmer, H. (2015). Stigmatisierungserfahrungen deutscher Besatzungskinder des Zweiten Weltkrieges. Trauma Und Gewalt, 9, 294-303.

Brendel, C (2002). Partizipation und partizipative Methoden in der Arbeit des DED. Ein Orientierungsrahmen Aus Der Praxis Für Die Praxis. Bonn: Deutscher Entwicklungsdienst (DED).

Chaitin, J. (2003). "I wish he hadn't told me that": methodological and ethical issues in social trauma and conflict research. Qualitative
Health Research, 13, 1145-1154. https://doi.org/10.1177/ 1049732303255997.

Freeman, T., \& Golombok, S. (2012). Donor insemination: a follow-up study of disclosure decisions, family relationships and child adjustment at adolescence. Reproductive Biomedicine Online, 25, 193-203.

Freeman, T. (2015). Gamete donation, information sharing and the best interests of the child: an overview of the psychosocial evidence. Monash Bioethics Review, 33, 45-63. https://doi.org/10. 1007/s40592-015-0018-y.

Glaesmer, H., Kaiser, M., Freyberger, H. J., Brähler, E., \& Kuwert, P. (2012). Die Kinder des Zweiten Weltkrieges in Deutschland-Ein Rahmenmodell für die psychosoziale Forschung. Trauma and Gewalt-Forschung Und Praxisfelder, 6, 319-328.

Glaesmer, H., Kuwert, P., Braehler, E., \& Kaiser, M. (2017). Childhood maltreatment in children born of occupation after WWII in Germany and its association with mental disorders. International Psychogeriatrics, 29, 1147-1156.

Golombok, S., Blake, L., Casey, P., Roman, G., \& Jadva, V. (2013). Children born through reproductive donation: a longitudinal study of psychological adjustment. Journal of Child Psychology and Psychiatry and Allied Disciplines, 54, 653-660.

Grieg, K. (2001). The War Children of the World. Bergen: War and Children Identity Project.

Ilioi, E., Blake, L., Jadva, V., Roman, G., \& Golombok, S. (2017). The role of age of disclosure of biological origins in the psychological wellbeing of adolescents conceived by reproductive donation: a longitudinal study from age 1 to age 14. Journal of Child Psychology and Psychiatry and Allied Disciplines, 58, 315-324. https://doi.org/10.1111/jcpp.12667.

Kaiser, M., Kuwert, P., Braehler, E., \& Glaesmer, H. (2015). Depression, somatization, and posttraumatic stress disorder in children born of occupation after World War II in comparison with a general population. The Journal of Nervous and Mental Disease, 203, 742-748. https://doi.org/10.1097/NMD.0000000000000361.

Kaiser, M., Kuwert, P., Braehler, E., \& Glaesmer, H. (2016). Long-term effects on adult attachment in German occupation children born after World War II in comparison with a birth-cohort-matched representative sample of the German general population. Aging \& Mental Health, 1-11. https://doi.org/10.1080/13607863.2016.1247430.

Kaiser, M., Kuwert, P., \& Glaesmer, H. (2015). Growing up as an occupation child of World War II in Germany: rationale and methods of a study on German occupation children [Aufwachsen als Besatzungskind des Zweiten Weltkrieges in DeutschlandHintergrunde und Vorgehen einer Befragung deutscher Besatzungskinder]. Zeitschrift Fur Psychosomatische Medizin Und Psychotherapie, 61, 191-205. https://doi.org/10.13109/zptm. 2015.61.2.191.

Lee, S. (2012). Kinder des Krieges: vergessene Sekundäropfer einer veränderten Kriegslandschaft im 20. Jahrhundert?. Trauma Und Gewalt, 6, 94-107. https://www.traumaundgewalt.de/index.php?url_ver=Z39. 882004\&rft_val_fmt=info:ofi/fmt:kev:mtx:journal\&rtf.jtitle=Trauma undGewalt\&rft.atitle $=$ Kinder + des + Krieges\&rft.volume $=6 \& \mathrm{rft}$. issue $=2 \&$ rft.spage $=94 \&$ rft.epage $=107$.

Lee, S. (2017). Children born of war in the twentieth century. Manchester: Manchester University Press.

McAdams, D. P. (2001). The psychology of life stories. Review of General Psychology, 5, 100-122. https://doi.org/10.1037/10892680.5.2.100.

Mochmann, I. C. (Ed.) 2013. Ethical considerations in doing research on hidden populations - the case of children born of war. Salzburg: Lecture at the Second International Multidisciplinary Conference "Children and War: Past and Present".

Mochmann, I. C. (2017). Children born of War-a decade of international and interdisciplinary research. Historical Social Research/Historische Sozialforschung, 42(1), 320-346. 
Mochmann, I. C., \& Kleinau, E. (2016). Kinder des Krieges in Gegenwart und Zukunft—Hilfestellungen und Selbstbemächtigung. In E. Kleinau \& I. C. Mochmann (Eds), Kinder des zweiten weltkrieges: stigmatisierung, ausgrenzung, bewältigungsstrategien. Frankfurt am Main, New York: Campus.

Mochmann, I. C., \& Larsen, S. U. (2008). Children born of War: the life course of children fathered by German soldiers in Norway and Denmark during WWII-some empirical results. Historical Social Research/Historische Sozialforschung, 33(1), 347-363.

Mochmann, I. C., Lee, S., \& Stelzl-Marx, B. (2009). The children of the occupations born during the second World War and beyond- an overview. Historical Social Research/Historische Sozialforschung, 34(3), 263-282.

Satjukow, S. (2009). Bankerte! Verschwiegene Kinder des Krieges. Bonwetsch, B.(Hg.). Kinder Des Krieges. Bulletin Des Deutschen Historischen Instituts in Moskau, 3, 57-69.

Stelzl-Marx, B. (2012). Stalins Soldaten in Österreich. Die Innensicht der sowjetischen Besatzung 1945-1955. Wien - München: Böhlau.

Stelzl-Marx, B. (2015). Soviet children of occupation in Austria: the historical, political and social background and its consequences. European Review of History. Revue européene d'histoire., 22(2), 277-291. 